\title{
THE PROBLEM WITH GRUBBY FOOTWEAR AT INTERNATIONAL BORDERS: A NEW ZEALAND CASE STUDY OF GOLFERS
}

\author{
T.D. WHITE ${ }^{1}$, T.A. PAYNE ${ }^{1}$, M.R. MCNEILL ${ }^{2}$ and D.T. BEWSELL ${ }^{2}$ \\ ${ }^{I}$ AgResearch, Ruakura Research Centre, Private Bag 3123, Hamilton, \\ New Zealand \\ ${ }^{2}$ AgResearch, Lincoln Research Centre, Private Bag 4748, Christchurch, \\ New Zealand
}

Corresponding author: tracy.payne@agresearch.co.nz

Due to New Zealand's geographical isolation, the country is free from many pests and diseases that are problematic in agricultural, horticultural and natural environments elsewhere. To help protect against incursions by new pests and diseases, biosecurity officers check and, if necessary, clean travellers' footwear as they enter the country. Golf shoes can collect and carry contaminants such as soil and leaf matter. If contaminated footwear is not detected at the border, it can provide an entry pathway for potential biosecurity hazards such as unwanted pests and diseases. This research examined the experiences of golfers returning to New Zealand after playing golf overseas, both in terms of their risk awareness and of their biosecurity experiences at the New Zealand border. Results show that $36 \%$ of respondents were unsure whether soil and leaf material found on golf shoes was a biosecurity risk, while $56 \%$ of respondents had not seen any information regarding the requirement for clean sport shoes when travelling. This may influence their response to biosecurity issues when travelling and returning to New Zealand. Raising awareness of the biosecurity risks and encouraging participation among golfers could be achieved through golf-orientated information packs that include cleaning brushes.

\section{TESTING THE EFFECTIVENESS OF DISINFECTANT PROTOCOLS FOR SOILED FOOTWEAR}

\author{
S.D. YOUNG, M.R. McNEILL and D.J. SAVILLE \\ AgResearch, Lincoln Research Centre, Private Bag 4749, Christchurch, \\ New Zealand
}

Corresponding author: sandra.young@agresearch.co.nz

Footwear carried by international air travellers arriving in New Zealand is subject to inspection, and if necessary cleaning and disinfecting by MAFBNZ quarantine inspectors. A study to evaluate the effectiveness of disinfectant treatment was carried out on three different types of footwear (running shoes, gumboots and tramping boots), cleaned following observed MAFBNZ procedure (dip) and following a 10 minute soak. Two disinfectant treatments (Virkon ${ }^{\mathrm{TM}}$ and TriGene Advance ${ }^{\mathrm{TM}}$ ) were compared with a surfactant (polysorbate 80) and water only. Soles were swabbed for microbes before and after washing and culturable bacteria and fungi per $\mathrm{cm}^{2}$ were enumerated. Disinfectant treatments reduced bacteria numbers by $99 \%$ compared with $98 \%$ for both water and surfactant treatments. Virkon ${ }^{\mathrm{TM}}$ was the best treatment for bacteria, both with the standard dip and the 10 minute soak, but it was not significantly better than the other treatments. Soaking also reduced bacterial numbers compared to the dip treatment, but not significantly. For fungi, the two disinfectants, surfactant and water yielded similar reductions $(97 \%)$. Soaking reduced fungal numbers compared to the dip treatment but this was not quite significant $(\mathrm{P}=0.051)$. 